\title{
DEMOCRACIA E ONTOLOGIA POLÍTICA EM MAQUIAVEL, SEGUNDO NEGRI: LIMITES DA POTÊNCIA CONSTITUINTE ${ }^{1}$
}

Douglas Ferreira Barros (PUC-Campinas) ${ }^{2}$

douglasfbarros@gmail.com

Devir-principe' é o processo em que a multidão aprende a arte do autogoverno e inventa formas democráticas duradouras de organização social. NEGRI, A. E HARDT, M. Bem-estar comum, 2009, VIII.

Resumo: $\mathrm{O}$ artigo investiga a tese negriana do Maquiavel democrático, observando a relação entre as noções de conflito, ontologia política e potência constituinte. Negri defende que a soberania democrática é sobredeterminação da ação do governante em face das resistências apresentadas pelos adversários e pela fortuna. O princípio da política é atividade resultante de movimentos para expansão da liberdade em confronto com os de contenção e instauração da paralisia anti-liberadora. Essa chave de leitura do conflito político, diz $\mathrm{Ne}$ gri, está na base da acepção maquiaveliana da ontologia política. Em Roma e em Florença conflitos e tumultos, bem como a deslegitimação da tirania e da opressão dos nobres sobre o povo traduziram historicamente esse movimento de constituição e destituição da liberdade. Negri apresenta sua versão da potência destituinte a partir da apreciação do projeto Homo Sacer, de Agamben. Veremos como certas passagens da História de Florença mostram-nos a paralisia oriunda nos tumultos e os limites das potências constituinte e destituinte. Nossa hipótese é que a constatação desses limites aproximam a abordagem filosófico política de Negri de uma avaliação sobre os princípios éticos da ação, visando à construção de novas formas de vida e de subjetividades liberadoras.

Palavras-chave: Negri. Maquiavel. Soberania democrática. Ontologia política.

1 Recebido em: 28-04-2018/ Aprovado em: 16-07-2018/ Publicado on-line em: 01-02-2019.

2 Douglas Ferreira Barros é Professor de Filosofia da Pontifícia Universidade Católica de Campinas, Campinas, SP, Brasil. 
Potência constituinte.

\section{MAQUiaVEl, EsPinOSA E A DEMOCRACIA}

O propósito do artigo é investigar os desdobramentos da tese negriana acerca do Maquiavel democrático, observando a relação entre as noções de conflito, ontologia política e potência constituinte. A avaliação de Antonio Negri acerca da linhagem do pensamento democrático na filosofia política é que essa tradição se iniciaria com Maquiavel, passaria por Espinosa e chegaria a Marx (2002, p.26). Pretendemos aqui, observar, a partir de Negri, em que sentido a democracia é na obra do pensador de Florença um arranjo político que não se reduz à forma de governo. Em seguida, passaremos à avaliação do conflito como elemento fundante de uma ontologia política. Centrados na noção de potência constituinte, pretendemos, ao final, interpretar passagens da História de Florença em que se destaca a paralisia decorrente dos tumultos constantes. Que diferença haveria entre os conflitos na cidade de Roma daqueles em Florença e por que nesta cidade os mesmos não alteraram as instituições para que exprimissem a liberdade e a potência constituinte?

O estudo da relação entre conflito e o poder é uma das componentes imprescindíveis da compreensão negriana da ontologia política, bem como do devir histórico. Desde seus escritos sobre Marx (1988), uma das investidas do projeto teórico de Negri consistiu em explicar a lógica do desenvolvimento da história e nela inscrever o ato político como momento da irrupção transformadora e instauradora de uma nova ordem política, assim como novas relações de poder e de dominação. Em Revolution and Time (2003), o 
autor escreve sobre o ser subsumido ao tempo da produção capitalista com vistas a formular a noção comunista do devir histórico, uma nova prática proletária do tempo (p.21). Negri defende que tal irrupção de nova práxis política é a própria transformação revolucionária, indutora de outra dinâmica para o desenvolvimento da história, fora daquela da produção capitalista.

Essa tomada sobre o tempo e a história se articula à análise do conflito entendido ainda sob o signo da luta de classes. Contudo, na trilogia pela qual Negri e Hardt ficariam conhecidos mundialmente $(2001 ; 2005 ; 2016)$ os autores apresentam o conceito de multitude para se referir aos que travam a luta pela liberdade e pela emancipação. Também, antecipam nova compreensão acerca do desenvolvimento do conflito e da dinâmica histórica, a qual pretende suplantar aquela da contradição entre proletariado e burguesia. ${ }^{3} \mathrm{~A}$ análise da multidão vem acompanhada da explicação sobre os elementos que compõem as circunstâncias específicas do embate da potência constituinte, possível instauradora da ruptura e prenúncio da reconfiguração do poder e da dominação políticos, e do poder constituído, que se esforça por conservar condições de opressão no presente. Seguindo tal investida encontramo-nos diante não apenas de uma nova dinâmica do conflito, como também reconfiguram-se os atores nele envolvidos. Concentrando nossa atenção em um momento anterior ao da trilogia, observamos nos textos negrianos sobre Maquiavel que o conflito é a própria matriz de uma ontologia política e a multidão encarna a luta da

\footnotetext{
${ }^{3}$ Para a compreensão da relação entre ontologia política e a noção de multitude nas obras de Negri, a partir da interpretação da mesma noção em Espinosa Cf.: Vittorio Morfino, The Multitudo According to Negri: On the Disarticulation of Ontology and History. pp. 227-238.
} 
potência constituinte.

Ainda que a referência ao pensador de Florença esteja dispersa em várias obras, dissemos acima que a leitura de Negri sobre Maquiavel se desenvolve em dois registros principais. $\mathrm{O}$ primeiro toma o texto maquiaveliano como sendo a primeira formulação da democracia moderna. $\mathrm{O}$ segundo procura demonstrar ali, a partir da análise de Roma e Florença, os princípios de uma ontologia política, ou uma ontologia da potência constituinte.

De acordo com o primeiro registro, a democracia não é mera forma de ordenamento do poder, uma forma de governo tal conta analisada por Aristóteles e Políbio. Em sentido mais amplo, ela é um "procedimento absoluto de liberdade" (2002, p.26) e um modo de conduta do poder absolutamente aberto e atento às tentativas do direito de fechá-lo. O direito, como elemento do poder constituído, tem por função estabelecer barreiras de contenção à potência constituinte, de modo a tornar o poder político impermeável às demandas das maiorias -da multidão de singularidades-, que gravitam à margem das decisões do poder e são indefesas quanto às determinações das instituições jurídicas. Maquiavel seria, então, o autor que iniciou o processo de liberação da potência produtiva da democracia.

Alinhado à tradição dos formuladores da democracia, o pensador florentino exerceu influência sobre a filosofia política de Espinosa. Diz Negri:

Com todo o peso do esforço revolucionário e libertário por detrás, desde o pensamento humanista republicano até os protestantes que lutaram contra a monarquia, [as lições de Maquiavel] ressoaram na definição espinosana de contrato social como 'o poder e a vontade de todos' (Theologico-Political Treatise, XVI, p.191) -quase como se isso 
fosse a antecipação de uma rigorosa posição política contra a 'vontade geral'! (1991, p.113).

O que em Maquiavel é a liberdade originada do conflito e da desunião entre o povo pequeno e o povo grande, como se vê no capítulo IX d'O Príncipe, em Espinosa é um processo que se distende entre singularidade e multidão, até se expandir como potência constituinte. Tanto em Maquiavel quanto em Espinosa, a potência "se expressa em desunião e luta” (2002, p.48). Negri destaca: “[...] em Espinosa, dilata-se em grande metafísica aquilo que em Maquiavel está implícito nas análises dos movimentos populares e da conflitualidade das repúblicas" (2002, p.48). Em ambos, o processo de instituição democrática como expansão do poder constituinte resulta da abertura da liberdade do povo à criação de novas experiências do poder, da dominação e da sujeição.

A liberdade democrática resultante do conflito da multidão e contra o poder constituído, diz Negri, teria sido empurrada pelos seus críticos para os limites do totalitarismo. Estaríamos nesta acepção diante de um claro equívoco de interpretação porque o totalitarismo emerge ao se negar ou se arruinar a potência constituinte da multidão. Ele afirma: "existe totalitarismo quando o enigma do poder constituinte não é revelado, quando sua efetividade potente é negada ou mistificada no poder constituído, quando sua radicalidade de potência metafísica e de desejos (cupiditas) coletivo é refutada" (2002, p.48).

O que está em destaque na análise dos regimes e das formas de governo não é bem o padrão e a estrutura do poder político, mas o estado das relações, o modo como estas se dão entre governantes e governados, a saber: como a multidão transige da obediência ao autogoverno, da sujeição para a liberdade criadora de instituições e da dominação 
opressora para a invenção da democracia aberta a todos os interesses e inclinações que envolvem os que dela participam.

Maquiavel e Espinosa desenvolvem uma concepção de democracia que não é uma "subespécie do liberalismo ou uma subcategoria do constitucionalismo" (2002, p.48). Em sua forma radical, ela é o avesso tanto da soberania moderna em senso estrito, quanto do totalitarismo. A democracia maquiaveliana é, para Negri, uma "forma da governabilidade" que se institui como potência constituinte e em oposição ao poder constituído.

Passemos então ao segundo registro da análise de Negri sobre os textos de Maquiavel, quando o autor procura demonstrar neles uma ontologia política, ou uma ontologia da potência constituinte.

\section{CONFLITO, ONTOLOGIA POLÍTICA E SOBERANIA}

A análise negriana do conflito como paradigma de leitura dos textos maquiaveliano se desenvolve, a nosso ver, em dois momentos demonstrativos da ontologia política. No primeiro, procura-se entender a relação entre movimento, transformações e ontologia política.

Em O Poder Constituinte (2002), Negri defende que a multidão, ao ser avaliada segundo a perspectiva da potência (potentia), aparece como o sujeito que abre o horizonte da transformação: a verdade da multidão é a lógica da revolução, a lógica do ser. A constituição do social complexo, diverso, múltiplo, não redutível a uma identidade de grupo ou classe- é o movimento próprio da potência constituinte que visa desestabilizar o poder constituído 
(p.26). Ele afirma:

o poder constituinte se define emergindo do turbilhão vazio...como uma necessidade totalmente aberta. É por isso que a potência constitutiva não se esgota nunca no poder, nem a multidão tende a se tornar totalidade, mas conjunto de singularidades, multiplicidade aberta (2002, p.26).

Em "Virtù e fortuna - o paradigma maquiaveliano", segundo capítulo da obra, Negri avalia os limites e as consequências de uma análise que põe o conflito entre a Virtù e a Fortuna como antessala da exposição sobre "liberdade democrática", tanto n'O Príncipe quanto nos Discursos. A exposição sobre a centralidade do embate Virtúfortuna estabelece que o movimento é elemento indissociável do acontecimento político; é o que constitui o cerne mesmo da política e a define. Diz ele: "o tempo histórico tem uma lógica inteiramente estruturada pela mutação" (2002, p.58). Referir-se à política em sentido maquiaveliano é, para Negri, pressupor também que a associação do movimento ao princípio da política não se obtém de mera analogia entre as instituições do poder e a dinâmica da natureza. A política, sempre em movimento, é atravessada pela ação humana que tenta engendrar uma nova ordem ao estado de coisas estabelecido. Negri chama de "sobredeterminação do destino" a intromissão humana nos eventos da história.

A operação fundamental de Maquiavel consiste em fazer da mutação uma estrutura global que é atravessada, enquanto globalidade, pela ação humana. Porém esta ação é ela mesma estrutural, estende-se pela globalidade do horizonte histórico, aferra e domina as variações do tempo, dando-lhes sentido e significado. Em outros termos: Maquiavel constrói uma função científica que arranca a mutação ao 
destino e faz dela um elemento da história; arranca a história ao passado e a considera como um contínuo temporal; arranca o tempo à continuidade e constrói a possibilidade de sobredeterminar o destino (2002, p.62).

Mutação, constata Negri, corresponderia a um primeiro estágio da demonstração da verdade política (2002, p. 57). O segundo estágio estabelece que a noção de mudança está atrelada à dinâmica dos conflitos que se observam tanto na ordenação do poder constituinte quanto na destruição do poder constituído. Assim, as duas verdades sustentadas por Negri recobririam toda a extensão da política em sua efetivação histórica: teríamos "de um lado, a verdade como contemplação da mutação; de outro, a verdade como ação sobre a mutação [...]" (2002, p.59).

Esse pano de fundo em duas dimensões nos possibilita entrever o que Negri pretende ao afirmar que a política "instaura a lógica do tempo sobre um horizonte ontológico de espessa materialidade, multifacetação, versátil” (2002, p.59-60). A expressão horizonte ontológico corresponde à multiplicidade das ações humanas em confronto com uma gama de eventos possíveis. Tal horizonte ontológico se estenderia desde a intervenção humana sobre a natureza 【cuja dinâmica é também marcada pela alteração incessantel, até a interferência na história. $O$ reordenamento de novo contexto político corresponde à construção de nova gramática da política.

No texto de Maquiavel esta novidade se observa na figura do Duque Valentino. ${ }^{4}$ Autoridade que tenta ordenar o es-

\footnotetext{
${ }^{4}$ Cf. "A Descrizione del modo tenuto dal Duca Valentino nello ammazare Vittellozzo Vitelli, Oliverotti da Femo, il signor Pagolo e il Duca di Gravina Orsini”. In: Tute le Opere. p.05.
} 
tado, apresentar uma nova dinâmica ao poder, "[...] que sobredetermina o tempo histórico e o reorganiza" (2002, p.64). O exemplo do Duque nos é apresentado em certa medida como horizonte possível, não o único, de ação política: uma tecnologia de intervenção, diz Negri, porque ele engendra constantemente novos limites e perspectivas de domínio e conquista ao poder. Suas ações não visam responder aos princípios supostamente verdadeiros encontrados nos manuais dos governantes. Ele conhece a vitória, experimenta a derrota, vê seus adversários triunfarem, perde os exércitos e sucumbe como prisioneiro do Papa Júlio II. Mesmo assim, Maquiavel admira tal governante irascível e gerador de conflitos os mais diversos. O que ela teria a nos revelar a respeito de uma outra acepção de soberania e da ontologia política? Nenhuma lição moral, mas, sim, que a preciosidade das suas ações se encontra na capacidade de inovar a política a partir da intervenção no presente. Que ele fracasse nessa intenção não constitui um problema maior. Valentino se apresenta como potência inovadora da conjuntura, do status quo político.

Na superfície, o jogo temporal é feito de fraude, de logro, de violência, de crueldades exemplares, mas na realidade ele é construído por rarefações e/ou precipitações do tempo, de longos silêncios, esperas sinistras, assaltos selvagens, surpresas ferozes, de lucidíssimas análises e de um frenesi de ação. Traído, isolado, eis Valentino a recolher e dissimular suas forças, mas pronto a desencadear uma repentina vingança, e capaz de fazê-lo (NEGRI 2002, p.64).

O governante é, então, aquele que se põe à prova, ciente de que uma vitória sobre qualquer obstáculo não é nada além do que resistência momentânea às armadilhas impostas pelo movimento próprio da política. Quem detém o poder é 
o agente da mudança, que sobredetermina a ordem estabelecida, dando-lhe uma nova gramática política. Ao mesmo tempo, ele não deixa de ser um tipo de refém iminente das transformações que atravessam qualquer forma de ordenamento do poder. Esse confronto que visa à reordenação política no tempo é a moldura de uma "ideia de soberania que nada deve ao direito comum medieval, nem ao contratualismo" (2002, p 64).

Em Maquiavel encontramo-nos diante de uma perspectiva da soberania cuja forma é dinâmica, muito ao contrário do que defenderão Bodin e Hobbes. Esses filósofos construíram suas obras para afirmar que a dinâmica própria do poder político é segura quando assentada sobre uma moldura suficientemente forte para resistir à mudança (Cf. 2002, p.48; p.154). Por isso, a defesa incondicional da soberania monárquica em ambos é inseparável da defesa da segurança política e da paz. Negri defende que o mito da imutabilidade se assentaria na verdade política estabelecida pelo poder constituído.

A figura do Duque anteciparia essa novidade de uma soberania que se molda segundo as circunstâncias históricas. Essa potência de transformação em face da necessidade é o elemento que sintetiza o lugar do governante à busca de se apossar do poder, conquistá-lo e mantê-lo. Sua inserção temporal repete de algum modo o enredo da tragédia; ela muda o sentido e o significado próprios da virtude segundo a acepção humanista clássica e introduz a inovação imprevisível, desconhecida, mas necessária: “...nesta inserção temporal, o humanismo torna-se trágico, enquanto a realidade afirma-se como a mais alta pulsação de inovação e vida" (2002, p.62). 


\section{O PRÍNCIPE E A REPÚBLICA: VIRTÚ-FORTUNA, CONTINGÊNCIA E ONTOLOGIA POLÍTICA}

O segundo movimento expositivo de demonstração da ontologia política em Maquiavel se concentra na interpretação do principado e da república. O principado, afirma Negri, não constitui apenas uma das formas em que o poder se ordena. O autor sustenta que não se encontra n'O Príncipe o tratado do bom governo, menos ainda das boas maneiras de como governar e manter seguro o poder, pilares sobre os quais se apoiam leituras consagradas.

Principado não é uma categoria da classificação polibiana, nem o modelo policiando do melhor governo, isto é, aquele que resulta da composição do governo de um com governo de pouco e o de muitos. Aqui, Principado é simplesmente a relação entre poder e mutação, entre potência e mutação, entre potência e poder. Ele é o sujeito histórico da sobredeterminação e da mutação (2002 p.74).

O príncipe é um novo paradigma; é a exposição de contextos de relações entre o poder, governos e comandados e quando centrado em uma figura como a do Duque é uma nova potência do agir no tempo -sobredeterminação. Nesse texto, pela ação do governante observaríamos a imbricação dos limites objetivos da ação com o contexto trágico. Residiria aqui o "desespero subjetivo e singular" (2002, p.75) do homem que age no mundo sem qualquer divindade que o ampare. Como análise dos contextos de relações que envolvem o comando e o poder político, a obra retrata um conjunto de ações sem solução definitiva. Negri destaca que essa "natureza aporética do texto" (2002, p.76) espelha o real da política. Maquiavel teria, segundo o autor, explorado ao limite o caráter irresolutivo das ações do príncipe. Vemos na 
obra as figuras dos governantes cercadas por impasses, vítimas de avaliações imprecisas e referências históricas que contradizem as diretrizes clássicas da ação política. Isso tornaria o texto inacessível a uma leitura que buscasse um fio retilíneo ligando os argumentos para a explicação do verdadeiro e único ato de governar. Pois,

a uma atenta e calma leitura, ele se revela uma especie de diário de bordo: inconcluso, e variado, dirigido numa terminologia insegura. ...a inovação ontológica está suspensa num vazios consequências, no desespero de um objetivo inatingivel” (2002, p.77).

Os atos do governante em todo o texto delineiam a renovação da gramática do poder enquanto potência produtiva, diz Negri. Ao fazer a defesa da virtù armada, das boas armas, a ação do príncipe novo introduz uma nova lógica de enfrentamento das forças de oposição -os poderes constituídos. Ele o faz não porque a tradição o favoreça, a ascendência familiar o autorize, os adversários assentem resignadamente em obedecê-lo, mas, sim, porque seus atos produzem novas condições de ocupação do poder político e de dominação. Para Negri, é disso que trata O Príncipe: fornecer uma lógica da produção das condições de resistência, conquista e dominação. Daí porque as armas são um instrumento de exercício do domínio, assim como o são as leis, o aprendizado dos costumes e da língua por parte de quem pretende conquistar. Nenhum destes fatores é por si mesmo condição suficiente e exclusiva da dominação. Combinados, eles permitem um mínimo de ordenamento do imprevisível em favor de quem comanda: eis a presença da virtù.

A potência do príncipe organiza, assim, a lógica do tempo, mas o faz sem alcançar conclusão. A verdade é sempre e tão somente efetiva. E 
a solidez desta verdade é um recorte operado na totalidade do ser. Toda afirmação é negação, mas a potência consiste além do limite, do encerramento, do corte. A tragédia tornou-se já um princípio dinâmico, o conceito mesmo do poder constituinte. A virtù constrói o mundo, e também o seu próprio limite - nisto consiste a tragédia da política. A efetividade desta situação é o seu caráter insolúvel: não há resolução para a política (2002, p.85).

Essa potência da virtù é a disponibilidade do príncipe Iseja ele um governante, um grupo, uma assembleial para fornecer uma forma política sobre as tentativas adversárias de desestabilização e fragilização de seu poder. Não se trata de imaginar que a imposição da virtù demarque a vitória definitiva sobre os opositores, o fim da luta na tentativa de instituição da nova ordem política. O limite de segurança que um poder mantém é a sua potência constituinte em confronto com outras potências que se constituem. Vimos acima, Negri observa que a tragédia é o que melhor traduz o cerne d'O Príncipe. Ele ressalta: "o choque entre o caráter contingente da ação e o caráter necessário de suas condições determina a tragédia política la tragédia de uma complexidade irredutível" (2002, p.83).

A compreensão abrangente da virtù na potência constituinte não se limita, porém, à ação do indivíduo, mas diz respeito também a todo o povo. A virtì é uma componente do horizonte ontológico multifacetado aludido pelo intérprete. Quanto então menciona a relação entre a virtù e armi próprie (2000, p.80), Negri nos fornece a exata dimensão deste alargamento: o povo armado é o próprio poder constituinte. Trata-se aqui da força expansiva do povo como constituição do poder. Ele afirma: as armas são a "dinâmica da constituição do principado, não somente no 
tempo da guerra, mas também no tempo de paz, já que organizam a cidade e a dispõem à virtù. Assim como a virtù é um princípio absoluto, as armas são a sua figura absoluta” (2002, p.81).

Todas as ordenações do poder estão atravessadas pelos embates. $\mathrm{O}$ conflito é o índice por excelência da dinâmica política e não a marca de um modelo débil ou forma de governo frágil, fadado à ruína. Não há em Maquiavel, segundo a perspectiva de Negri, uma compreensão positiva da política, como se as soluções estivessem à mão do governante $\mathrm{e}$ os resultados the fossem quase sempre favoráveis. A já mencionada nova gramática do tempo se compõe de transformação e não de vitórias definitivas ou derrotas insuperáveis. Que figuras da obra de Maquiavel melhor representam tais forças em conflito a não ser a virtù e a fortuna?

O conflito localizado na oposição virtù-fortuna acentua n’O Principe o caráter transitório, contingente, do poder político e das formas em que ele pode estar constituído (principato, libertà ou licenzia). O capítulo XXV, no qual lemos que é próprio da vitrù fornecer resistência, tanto quanto possível, à fortuna, nos fornece também a imagem desse horizonte ontológico da contingência permanente que atravessa o poder. A virtù está associada às qualidades guerreiras do governante e à idéia de que os homens devem forjar por si mesmos seu próprio destino nos embates com as variações da fortuna (Cf. SKINNER, 2003, p.121). Não há no capítulo uma definição específica para a virtù, mas esta pode ser constatada em todo o livro a cada momento em que os governantes se põem a reorientar o curso desfavorável dos 
acontecimentos. Também, a virtù não é mais uma deusa como pensavam os romanos-, mas um procedimento, modo de agir, que visa reordenar os acontecimentos de modo que estes favoreçam o autor da ação. Pensada sempre no horizonte da ação humana, a virtù está diretamente associada à liberdade (Cf. BIGNOTTO, 1991; SKINNER, 2003). Daí porque, em Negri, a virtù é compreendida como signo da potência constituinte e da liberdade. Ela é força de expansão e de imposição dos desejos; deve-se a ela a construção do ordenamento político possível: é força de engendramento e de fortalecimento do conflito. Ao que se pode denominar também: potência da construção política. Se a virtù é força de construção, por que Negri afirma que "o cerne de $\mathrm{O}$ Principe [...] é a tragédia do poder constituinte" (2002, p.82)?

O Príncipe é um acúmulo de contradições, o ponto de partida de caminhos que se interrompem [...] $\mathrm{O}$ andamento de seu pensamento [de Maquiavel] é aquele do antagonismo, e não o da tendência; interessalhe a crise, não a solução da crise - ele até busca continuamente essa solução, mas sabe que não pode encontrá-la (2002 p.77).

Como vimos acima, o princípio constituinte é potência afirmativa pela qual o homem de ação tenta manter a suposta solidez da ordem estabelecida e pretende transformá-la, mudá-la. Negri defende que compreeder a política como atualização do conflito é o princípio "constituinte de Maquiavel", o ponto que o faz "subversivo, apenas subversivo" (2002, p.77). O que Negri pretende não é estabelecer uma análise da obra maquiaveliana sob o signo da crise intermitente -não se trata de um ceticismo em relação à possibilidade de instituição de um ordenamento-, mas, sim, reforçar a tese do antagonismo como "trabalho de 
escavação em busca da definição do princípio constituinte, em busca da configuração do príncipe novo” (2002, p.77).

\section{ROMA, SOBERANIA DEMOCRÁTICA E O POVO COMO AGENTE DA LIBERDADE}

Negri observa "estreitíssima interdependência" entre $\mathrm{O}$ Principe e os Discursos. ${ }^{5}$ Em ambas as obras, nota-se que é central o caráter "absoluto da política" expresso no conflito. Maquiavel parte de um lugar único entre os pensadores da política na modernidade e Negri pretende explorar a primazia da política em face de outros campos de saber acerca da ação humana. A primeira obra destaca a potência do homem de ação que, em face do adversário -da fortunatenta introduzir alguma ordem no tempo. $\mathrm{Na}$ segunda, as ações dos grupos em conflito nos mostram a potência da soberania democrática. Veja-se que a lógica do conflito perpassa uma e outra obras, projetando-se na segunda para dar forma e configurar um ordenamento político específico -a república. Lembremo-nos de que n'O Príncipe não encontramos a defesa de uma forma de governo. Os Discursos põem em destaque os conflitos na república. Nesse novo contexto, como localizar o conflito da potência constituinte?

\footnotetext{
${ }^{5}$ A respeito das diferentes perspectivas de interpretação d'O Príncipe e dos Discorsi, Negri comenta: "A interpretação da relação entre O príncipe e os Discorsi sempre foi tormentosa - não somente por razões filológicas, mas também por motivos filosóficos e políticos. Ao insistir na síntese entre as duas obras, na sua integração numa mesma linha de pensamento, a tradição interpretativa italiana dominante tende a afirmar que o primado de O Príncipe e a exaltar o conceito de autonomia da política que, a partir de tal primado, está presente em toda obra maquiaveliana. De outra parte, a corrente interpretativa anglo-saxã, ao insistir sobretudo na distinção, ou melhor na discrepância substantiva entre as duas obras, tende a privilegiar os Discorsi pelo seu tom republicano e pela ideia de governo misto que os percorre. Quanto a O Príncipe tratar-se-ia essencialmente -segundo os autores que integram esta tendência interpretativa- de uma obra de circunstância, isto quando não acrescentam que se trata de uma obra substancialmente equívoca" (2002, p.93-4).
} 
A construção do ordenamento político republicano em Maquiavel visa a efetivação de horizontes possíveis da liberdade do povo. Em outra chave, pode-se dizer que na acepção maquiaveliana os conflitos na república se furtam à aplicação de modelos ou fórmulas que engessem a sua participação. A cidade de Roma que encontramos em seus textos é atravessada por tumultos entre plebeus e nobres, obrigada a introduzir mudanças constantes para satisfazer uma e outra partes. Por isso, encarna o exemplo da antiutopia ao levar a experiência do conflito, da luta por interesses, ao limite entre a inovação da potência constitutiva e o desejo de interrupção da liberdade pelo poder constituído, o que se observou com a ascensão dos imperadores.

Os conflitos entre plebe e nobres não resultaram em destruição. Todos se defrontaram com o êxito e a derrota de suas posições. Experimentar a liberdade, o sentido mais profundo da prática republicana, não poderia ser outra coisa senão afirmar a oposição, pretender derrotar o grupo adversário, ampliar o horizonte de transformação política ao conjunto dos cidadãos, sem exclusões prévias. Negri entende essa característica de Roma como outro momento do processo de construção radical de uma ontologia política da soberania democrática. Pois,

[...] de fato, a relação entre virtù e fortuna não é dialética, nem recíproca, nem funcional. [...] existe somente um movimento tão profundo da vontade de potência que ela dispara em frente, que ela transforma radicalmente o real e põe em funcionamento um mecanismo irresistível. Uma desutopia absoluta. Uma ontologia da construção radical [...] (2002, p.88-9).

A diversificação dos interesses, a ampliação dos embates 
entre representantes dos tribunos da plebe e os do senado tornou os conflitos uma prática multifacetada de construção da potência coletiva. Diferentemente da concepção de Políbio para a qual o governo misto produz equilíbrio, nos Discursos Maquiavel exalta novamente o caráter dinâmico e incessante das transformações. O historiador grego de Roma observa nessa cidade "[...] uma situação teórica e histórica totalmente estática: as consciências e leis sofrem um embotamento geral, a realidade institucional é degradada, e a realidade natural padece com o infortúnio" (2002, p.102). Negri ressalta que o princípio da potência constitutiva que se observou n'O Príncipe se amplia na Roma republicana. Mesmo assim, esta última teria encarnado o sentido mais exato da ontologia política em sentido maquiaveliano.

Somente o princípio oposto, o princípio do príncipe, pode arrebatarnos desta condição. Ele reabre a gênese das constituições, ele é a própria potência que as faz viva [...] a desunião não pode ser detida e bloqueada no equilíbrio da constituição mista, mas deve ser interpretada e inovada incessantemente por um princípio potente e dinâmico (2002, p.102).

A defesa da desunião como o princípio da potência demarca outro momento da alteração maquiaveliana face ao passado do pensamento filosófico-político. A inovação surge do fato de que o destaque conferido à luta entre os plebeus e os ricos patrícios resultou no enfrentamento do temor dos primeiros em relação aos segundos, padrão de dominação política largamente apresentado em textos clássicos, como os de Platão. Segundo a nova compreensão maquiaveliana, diz Negri, o povo passa à condição de sujeito na efetivação da 
liberdade. ${ }^{6}$ A tese de Políbio é suplantada pela percepção de que o povo é agente da potência de mudança. E completa:

Após fazer-se sujeito coletivo e mostrar sua potência coletiva, a virtù se aperfeiçoa por 'prudenza intrinseca' - ela passa da experiência da objetividade à experiência das paixões; rearticula, internamente, virtú e efetividade e, pela base, os dispositivos que geram o processo constituinte. Não é o Estado absolutista moderno que é construído aqui -tal degeneração deve ser deixada aos antimaquiavelismos (2002, p.115).

Negri tem em vista que nos Discursos os pressupostos de um pensamento maquiaveliano democrático estão perfeitamente delineados. A abertura -expansividade do modelo maquiaveliano comparado ao de Políbio-, corresponde tanto à formulação dos elementos basilares da democracia moderna. Diz Negri: "só existe democracia onde existe poder constituinte" (2002, p.114), força de mudança, potência de transformação advinda do povo em confronto com estruturas promotoras da opressão e que tornam o poder inacessível aos pequenos, aos pobres.

\section{CONFlitos EM FlorenÇA E OS LIMITES DA POTÊNCIA CONSTITUINTE}

Em História de Florença, apesar do "estilo naturalista e compilativo" da narrativa, Negri observa que Maquiavel procura "redescobrir verdades de que havia tratado amplamente

\footnotetext{
${ }^{6}$ Aqui vale observar a advertência de Negri quanto ao emprego do termo sujeito: "É totalmente evidente que esta concepção de subjetividade, mesmo na sua implicação democrática, é equívoca. De um lado temos a possível leitura 'gramisciana' desta subjetividade, que visa a evidenciar as determinações populares, 'democráticas' em sentido estrito; de outro, uma possível leitura 'republicana' (como a de Pocock [...]), visando a caracterizar a determinação democrática como apêndice da ideologia 'cívica"' (2002, p.105, nota 231).
} 
n'O Príncipe e nos Discorsi" (2002, p.112). De que verdades se tratariam numa obra dedicada à história?

As análises de Negri percorrem celeremente cada um dos livros, mas o autor nota ser possível estabelecer no conjunto uma divisão, segundo a qual entre os livros I e IV tudo se nivela pela tradição e se encontra aí a inovação metodológica. Daí em diante -livros V ao VIII- encontramos uma "postura filosófica epicurista pessimista” (2002, p.130). Sem nos explicar com precisão a que se refere tal "postura epirurista", Negri observa o desenvolvimento de uma postura crítica em relação à história de Florença. Tanto na parte em que se destaca o caráter metodológico crítico, quanto na parte pessimista acerca da possibilidade de que ocorra a mudança como resultante dos conflitos, nota-se que Negri está à procura dos vestígios da presença da potência constituinte da multidão. Também em Florença se observou o povo disponível ao conflito contra os grandes. Mas, que trama política original teria se passado nessa cidade para que ali o povo não experimentasse a liberdade como o fizeram os romanos?

Roma e Atenas tiveram os nobres contra a plebe, mas em Florença o conflito é universal, em todas as direções, em todos os sentidos. Tal é o paradoxo, mas é o próprio cerne do discurso de Maquiavel: nada pode demonstrar melhor a excelência e a potência de Florença do que o fato de não haver desmoronado sob o peso de suas dissensões, de haver feito de tais dissensões a mola mestra de seu progresso (2002, p.127).

Há no trecho certo desapontamento quanto ao teor da potência constituinte florentina. Teriam então seus habitantes feito a experiência do conflito se degradar em destruição ao invés de produzir a liberdade? Na avaliação 
negriana do principado e de Roma a consequência imediata teria sido a ampliação da liberdade, que se deslocou da experiência de sujeição dos cidadãos a um governante para a experiência do conflito entre pequenos e grandes, plebeus e nobres. Em Florença, o aspecto a se destacar dos conflitos generalizados foi que a cidade não se autodestruiu. Ao invés do conflito ter engendrado a mudança em benefício da liberdade, os embates "em todas as direções" teriam gestado um tipo de desejo menos nobre, de não destruição. Além disso, o horizonte de constituição da potência liberadora teria sido frustrado pela própria qualidade das instituições e dos governos da cidade. No entanto, por pior que fossem, as instituições de Florença não permitiram que a cidade deslizasse da experiência dos conflitos generalizados para o abismo da destruição completa.

Negri observa esse movimento de resistência à dissolução como revelador também de uma dimensão da ontologia política (2002, p.127). A história de Florença encarnaria um paradoxo: de um lado, o conflito generalizado; de outro, o movimento de reação da cidade para não se autodestruir. A permanência dos tumultos pode ser entendida também como a reação contra as tentativas de contenção do conflito, de imobilização do antagonismo pela sedimentação de um status quo nas instituições, impermeável à participação e às reivindicações do povo. Pois,

a ordem das coisas encontra em sua base a ação, a dissensão -motor e sentido do processo histórico. O ser é constituído pela práxis humana que se organiza na desunião universal, e é através da desunião que se descobre e organiza o poder constituinte. Após termos visto, [...], o poder constituinte formar-se, em meio à mutação, como descoberta da possibilidade de sobredeterminar do tempo; após demonstramos [...] que o caráter absoluto do poder constituinte pode encontrar tão 
somente na multidão um sujeito adequado, e tão somente numa forma sempre aberta de governo democrático sua substância, vamos agora [com análise da História de Florença] trazer à luz o materialismo desta fundação: aquele elemento que faz do pensamento de Maquiavel o melhor antídoto contra toda tentativa de pacificação da história e do antagonismo social, contra toda negação do trabalho constitutivo da ontologia (2002, p.127).

Se a experiência de Florença não se completa com a efetivação da liberdade democrática, que desarranjos do conflito poderiam explicar a anomalia nessa cidade? $\mathrm{O}$ conflito generalizado teria sido a causa determinante da fragilidade institucional de Florença? Negri interpreta sobre a História de Florença que o conflito específico dessa cidade não traduziu a universalidade e a radicalidade da luta de classes. Porque "a vitória da burguesia destrói a democracia, a fortuna repele e esmaga a virtü" (2002, p.147). O conflito que em Roma tornou concreta a experiência da liberdade; em Florença se projetou como horizonte utópico, irrealizável. Indaga Negri: "em que momento o projeto democrático do poder constituinte torna-se utopia?" (2002, p.147). Ora, tornar-se utopia é em certo sentido admitir a desfiguração da potência constituinte. A pacificação e a domesticação dos conflitos pelos ritos e preceitos institucionais configuram o abrandamento e o fim da potência transformadora. Continua Negri:

Quando, ultrapassada a crise, o poder constituinte vier a reencontrar o sujeito em seu caráter absoluto, somente então será possível responder ao desejo de democracia. [...] Em que momento a ciência cede ao mito? As Istorie nos mostraram: quando a luta de classe dos proletários florentinos tem que ceder à ideologia razoável e à pacificação dos Médicis (2002, p.147).

Estaríamos na História diante do relato sobre o fracasso 
do processo constituinte? Se não é correto concedermos vitória ao ceticismo político mencionado acima, é válido reconhecer a importância da reação contra a dissolução política completa que o texto apresenta. A respeito do impasse entre constituição e destituição, o filósofo Giorgio Agamben pondera que em uma pesquisa filosófica acerca do poder e da soberania a pars destruens não pode estar separada da pars construens (2014, p.09). Segundo a perspectiva agambeniana, uma teoria que está alheia ou elimina de seu corpo os equívocos políticos "não tem razão de existir e não pode subsistir separada da práxis" (2014, p.09). Esse autor defende que não se pode admitir um conflito entre opostos no qual os atos para a constituição e a desconstituição de um novo estado de coisas estejam apresentados em separado.

A proposta de Agamben acerca da potência destituinte, em L'uso dei corpi (2014), mantém fios de conexão com a interpretação de Negri sobre Maquiavel. Ao jogar luz sobre o tema da potência constituinte e suas falhas, o primeiro realiza uma arqueologia política para estabelecer a crítica do estado de exceção como regra da atuação do poder soberano na contemporaneidade. Se compararmos o projeto agambeniano com o de Negri, de pronto se observará que os trabalhos do segundo avançam por outro caminho em sua crítica da soberania. Entretanto, Agamben retoma, no Epilogo - Per una teoria della potencia destituente-, a discussão sobre a archè do poder em nossa cultura. Defende que em sua estrutura o poder soberano encontra-se ao mesmo tempo dentro e fora do ordenamento legal. Por deter a prerrogativa de decretar a exceção, o poder soberano se retira do ordenamento a que pertencia e no qual se encontrava 
limitado.

Como Maquiavel, Agamben defende que a cidade se funda em uma cisão (2014, p.336). A diferença entre ambos é que o segundo entende que a regra da atuação do governo soberano é a exceção em relação à lei e ao arcabouço jurídico. A exceção não divide a cidade entre grupos que entram em conflito para ampliar a própria liberdade; instala uma fissura talvez irrecuperável: de um lado, abriga-se na cidade a vida nua, de outro, a vida politicamente qualificada. A vida nua é aquela inteiramente disponível à ação do poder e destituída de quaisquer direitos. Desde a obra Estado de Exceção (2003), Agamben aprofunda a tese segundo a qual a máquina jurídico-política do ocidente poderia ser descrita como possuindo uma dupla estrutura: "formada por dois elementos heterogêneos e, todavia, intimamente coordenados: um normativo e jurídico em sentido estrito (potestas) e um anômico extrajurídico (auctoritas)" (2014, p.334). O elemento jurídico atua conjuntamente ao anômico para exercer o poder sobre a vida. $\mathrm{O}$ estado de exceção é o dispositivo que deve articular e manter juntos os dois aspectos da máquina jurídico-política: a zona de indecidibilidade entre "anomia e nomos, entre vida e direito, entre auctoritas e potestas" (2014, p.335). Quando, então, ambos os aspectos -anomia/exceção, nomos/lei que se impõe a todos- coincidem nos atos de dominação e opressão exercida por uma só pessoa -o soberano-, quando o estado de exceção se torna a regra, o "sistema jurídico-político se transforma em uma máquina letal” (2014, p.335).

Se retomamos o texto maquiaveliano dificilmente concluiremos que a avaliação do florentino acerca do 
conflito em Florença possa abranger esse tipo de atuação do poder explicitado por Agamben. O Proemio do livro III da História nos informa sobre a graves e naturais inimizades e discórdias existentes entre o povo e os nobres em Roma e Florença (1998, p.143). Maquiavel mantém, como fizera em O Principe e nos Discursos, que os conflitos resultam do desejo dos nobres de mandar e do povo, de não querer obedecer. No caso de Florença, as oposições "são os motivos de todos os males que surgem nas cidades, porque desta diversidade de humores nutrem-se todas as outras coisas que perturbam as repúblicas" (1994, p.143). Em Roma, as oposições se encerraram por meio das discussões; em Florença redundaram em combates intermitentes. $\mathrm{Na}$ primeira, os embates resultaram nas leis, na segunda deram origem à "morte a ao exílio de muitos cidadãos". Naquela, terminaram por aumentar a virtude militar e conduziram "de uma igualdade entre os cidadãos a uma gravíssima desigualdade, [enquanto] nesta de uma desigualdade a uma assombrosa igualdade reconduziram" (1994, p.143). Conclui Maquiavel:

[...] mais razoável era o desejo do povo romano, eram as ofensas aos nobres mais suportáveis, assim essa nobreza facilmente e sem vir às armas cedia, de maneira que, satisfizesse o povo e mantivesse nos nobre sua dignidade. Por outro lado, o desejo do povo florentino era injurioso e injusto, por isto a nobreza com maiores forças às suas defesas se preparava, e assim ao sangue e ao exílio dos cidadãos se chegava; e as leis que depois se criavam, não à utilidade pública, mas ao vencedor todas beneficiavam (1994, p.143-4).

Que gênero de ações poderia ser mais nefasto do que daquelas resultantes de um desejo injurioso e injusto? Com a vitória do povo, Roma se tornava mais virtuosa e crescia em 
potência; em Florença, a vitória do povo gerava nos nobres os atos de dissimulação: "[...] ficavam os nobres despojados de magistrados; e desejando readmiti-los, era necessário com os governos, com o ânimo e com o modo de viver, não só ser semelhantes ao povo, mas parecê-lo" (1994, p.144). Que elementos específicos da relação entre o povo e os nobres em Florença geravam a fragilidade e a dissimulação? Apesar de ter experimentado a liberdade já no seu nascimento, escreve Maquiavel na História, por fim, as divisões e cisões entre os florentinos resultaram na tirania do Duque de Atenas (1994, p.144) sobre os seus próprios cidadãos. Como qualificar as disputas nessa cidade?

Em Stasis (2015), Agamben chama a atenção para a importância de se retomar a investigação sobre a guerra civil. Ele pondera ter havido pensadores contemporâneos que aprofundaram o tema em nível mundial (ARENDT, 2011; SCHMITT, 2014), mas a atenção dada pelos estudiosos do final do século XX não foi suficiente para fundar uma nova teoria. Estes apenas estabeleceram "uma doutrina do management, isto é, da gestão, da manipulação e da internacionalização dos conflitos internos" (2015, p.11). Entretanto, dois momentos na história do pensamento, diz Agamben, aprofundaram a contento uma teoria da guerra civil. Primeiro, o do testemunho dos filósofos acerca dos eventos da Grécia clássica e, segundo, o pensamento de Hobbes. Enquanto entre os gregos aprendemos que a guerra civil teria sido inevitável, em Hobbes somos levados a pensar que ela deve ser excluída do horizonte político das repúblicas (2015, p.12).

A guerra civil -stasis-é uma cisão que ocorre no interior 
família. A partir das análises de Loraux (1997a), Agamben mostra, entre outros aspectos, que a guerra civil tem seu início no oikos e não no exterior. Ele afirma: "precisamente porque é inerente à família, a stasis atua como reveladora dela, atestando sua presença irredutível na polis" (1997a, p.19). Também, o oikos é ambivalente: de uma parte é fator de divisão e de conflito; de outra, é "paradigma de reconciliação do que estava dividido” (1997a, p.19). Como é possível, ao mesmo tempo, que o oikos resguarde o elemento desagregador na pólis -stasi- e constitua o modelo agregador e da união entre os que habitam o mesmo lugar? Diz Agamben: aqueles cidadãos que se projetam na stasis, pela própria dinâmica da pólis, são expulsos para o oikos. As sobrevivências da pólis e da política, em sentido mais amplo, dependem da circunscrição da stasis no interior do ambiente mínimo da convivência entre os cidadãos. A formulação de Maquiavel acerca das cisões e dos conflitos em Florença indicaria a contaminação da cidade pela stasis?

Sem se ocupar de Florença, Agamben defende que tanto a tese da potência destituinte quanto a tentativa de reavaliação da guerra civil são parte do mesmo ato de colocar em questão os pressupostos da noção de soberania na contemporaneidade. $\mathrm{O}$ que está em jogo no projeto Homo Sacer agambeniano é prioritariamente a identificação da vida nua e a crítica dos mecanismos de poder que atuam sobre a mesma, tornando-a vida matável e que de modo algum viria a ser vida qualificável $(2002 ; 2014$, p.333). Tal enfoque da soberania pelo viés da vida sacrificável parece se distanciar da perspectiva de Negri. A defesa de uma potência destituinte se apresenta como resposta negativa ao projeto negriano da 
potência constituinte. $\mathrm{O}$ desarme ou desmonte da máquina governamental deixa evidente a desconfiança de Agamben quanto a todo e qualquer impulso constituinte -defendido por Negri-, tenha ele suas bases plantadas no conflito de classes ou nos interesses de transformação social, próprios do proletariado e da multidão no processo constituinte. Entretanto, justamente com relação ao tema da potência constituinte o estudo da Stasis se coloca em diálogo com a interpretação negriana de Maquiavel acerca do conflito em Florença.

Em comentário ao projeto Homo Sacer, Negri direciona sua atenção ao tema da inoperosidade. Destaca que, após 20 anos, o trabalho agambeniano não se encerra "nem na construção de uma comunidade possível, nem na definição de uma potência - a menos que se considere como tal a 'potência destituinte', desejada na conclusão da pesquisa” (2014). Negri ressalta que a proposta de busca pela vida feliz a ser conquistada politicamente reafirma que a política é uma prática. $\bigcirc$ trabalho destituinte é, também e simultaneamente, a constituição de uma nova forma de vida. E afirma: "a felicidade consistiria na singular contemplação de uma 'forma de vida' que recomponha zoé e bíos e, por outro lado, na desativação da sua separação, imposta pela dominação” (2014). Na nova forma de vida, "a potência se apresenta como uso inoperoso". A inoperosidade seria assim uma conquista política resultante de uma nova prática de comando e de relação dos homens e mulheres, e da comunidade, com o poder. Ele conclui:

[...][nessa nova experiência do poder e da política, que ultrapassaria o poder constituído a] 'vida nua' não seria, então, mais isolável por parte do poder; aqui, no entanto, estaria o princípio do comum: 
'comunidade e potência se identificam sem resíduos, porque o ato de forjar um princípio comunitário em toda sua potência é função do caráter necessariamente potencial de toda comunidade (2014) [tradução minha].

Negri não assente nem recusa as conclusões de Agamben acerca da inoperosidade. Mas, se pergunta: "Como dar futuro à forma de vida e potência à inoperosidade: à "potência destituinte?" (2014). Ele não observa os dois projetos -o da potência constituinte e o do Homo Sacer- como excludentes entre si. Ambos, em diferentes chaves de leituras teóricas e de interpretação do presente, lançam dúvidas e são antagônicos às formas de exploração estabelecidas pelo poder soberano na contemporaneidade. Negri ressalta o distanciamento de Agamben em relação a Heidegger e a Foucault para afirmar a possibilidade da instauração de novas formas de vida e destas se estabelecerem em liberdade. Todavia, o que Agamben observa ser uma alternativa éticopolítica -a potência destituinte-, é na avaliação de Negri uma "fuga do ser na qual até mesmo o conflito contra o nada é convertido novamente em felicidade" (2014). Este pensador adverte:

os volumes anteriores de todo o curso do Homo sacer faziam suspeitar [que] essa inoperosidade devia se realizar em um abraço sem alegria e onde só restaria o contato, pontual e desesperado, com o nada desse testemunho do ser. Agora isso está dito. Quanta dor há nisso" (2014) [tradução minha].

Uma vez que o poder constituinte é "desejo, movimento, relação de força” e está posto em relação assimétrica em face do poder constituído parece que a crítica da soberania em Negri não estabelece diálogo evidente com aquela crítica estabelecida por Agamben. A proposta da potência 
destituinte parece mirar em outra direção que a da dinâmica do poder constituinte. No entanto, Negri se recusa a quebrar algum possível fio que as possa conectar. E sustenta que a tese da inoperosidade agambeniana é apenas um desvio (desnecessário?) na crítica da soberania.

Mas, tal deslocamento, se ele "pretende esclarecer essa dinâmica constituinte e, portanto (sem que ele o queira), esclarecer também o efeito destituinte que nele vigora, [então] o desvio é útil" (2014). A utilidade, ou o fator desconcertante do desvio, reside em que revela a face perversa do poder constituído, o modo como este atua para neutralizar e fragilizar o poder constituinte. No entanto, Agamben põe em dúvida a possibilidade de que alguma forma de potência constituinte não se degenere em soberania perversa, que isole a vida nua e sobre ela atue como algoz.

Diran (2017, p.277) destaca que a crítica agambeniana defende haver estreita relação da potência constituinte com a noção de soberano concebida por Schmitt. Afirma: "Agamben defende que o compatriota 'não encontra qualquer critério em sua ampla análise da fenomenologia histórica do poder constituinte', a partir do qual isola o poder constituinte do poder soberano (Homo Sacer, p.43)" (2017, p.277). Desse modo, aquela livre, produtiva e contínua praxis defendida por Negri produz não a "totalidade democrática", mas, ao invés disso, a verdadeira soberania da lei, a qual se esperava que o poder constituinte fosse capaz de resistir e transformar radicalmente o poder constituído (2017, p.278). Quando pensa em uma potência destituinte, Agamben:

elabora sua contra-tese (do homem como argos, essencialmente inoperante, improdutivo), é para imaginar formas de atividade, incluindo atos de produtividade, que, precisamente por operação, desativam e 
tornam inoperante. Em outras palavras, deseja definir um reino de praxis - que ele também chamará de uso - que exibe completamente a atualidade da impotência, a existência de um potencial não-para, separado de um telos produtivo. Agamben lista entre os exemplos de tal operação de desativação (ou potência destituinte): atividades realizadas em um feriado durante o qual se come, mas não tanto para estar nutrido; no qual se veste, mas não para se aquecer, no qual se trocam bens (presentes) não como commodities; no qual se escreve o poema como uma operação na linguagem que desativa sua função comunicativa; e, mesmo, se pratica o próprio ato da fala, que 'desvia a boca de sua função [digestiva] para torná-la o lugar da linguagem (2017, p.279).

Entretanto, para Negri, a potência constituinte contém em si algo de potência destituinte. Importa menos neste momento reconhecer que a solução ética apontada por Agamben não esteja entre as alternativas políticas vislumbradas no movimento da potência constituinte. Negri mantém que não há movimento expansivo da liberdade sem a potência constituinte confrontando a constituída, sobredeterminando-se. Assim, a potência destituinte é tão somente um desvio no movimento constituinte; momento necessário porque é desestabilizador e não está isolado da potência constituinte. Estaria aqui o ponto de conexão entre os dois projetos: a potência constituinte tem junto a si, quando em face do poder constituído, a potência destituinte. Sem isso, não haveria como suplantar o amálgama que recobre as instituições do poder constituído, impermeável às demandas da multidão.

A constatação de Negri acerca da proximidade entre as potências constituinte e destituinte, embora resulte de recente avaliação sobre o projeto de Agamben, nos ajuda a entender também aspectos da sua interpretação sobre Maquiavel. Um exemplo é a ênfase dada pelo autor ao tema 
das fissuras e diferenças entre os conflitos e os ordenamentos políticos. Uns são resultantes da potência constituinte e do desejo de expansão da liberdade -Roma-; outros resultam daquelas lutas constantes que expressam a potência irrealizada -Florença. Seguindo o argumento de Negri, poderíamos inferir que o elemento destituinte nos embates entre o povo e os nobres em Florença não desestabilizaram as instituições a ponto de torná-las abertas à liberdade republicana. $\mathrm{O}$ desvio destituinte não teria sido potente o suficiente para desestabilizar o poder constituído e instaurar uma nova forma, mas fora o bastante para estacionar as instituições em meio a lutas partidárias que tornaram a cidade e seus poderes mais frágeis e instáveis. Se tomarmos como referência o tema da Stasis poderíamos acrescentar que em Florença nem o povo, nem os nobres conseguiram isolar a guerra como um evento do óikos e retirá-lo do centro da pólis, domesticando-o a ponto de se tornar um conflito de interesses próprio de uma cidade livre e potente.

\section{Conclusão: Negri, Agamben e a instituiçÃo de NOVAS FORMAS DE VIDA}

Procuramos mostrar que a interpretação negriana acerca da ontologia política e da soberania democrática em Maquiavel nos permite estender a compreensão sobre certos limites da noção de potência constituinte. Tanto no caso de Roma quanto no de Florença, a tese da política como resultante de movimentos para expansão da liberdade ou para a contenção e instauração da paralisia anti-liberadora se desenvolve tendo como pano de fundo uma concepção da ontologia política. $\mathrm{Na}$ acepção de Negri, O Príncipe e os Discursos nos 
possibilitam observar o avanço da potência constituinte da liberdade, o movimento instituidor da soberania democrática e ao mesmo tempo desmobilizador e destituinte do poder constituído. Já na História a paralisia resultante das guerras denota o esgotamento das instituições e do desejo de liberdade do povo. A potência destituinte inerente aos movimentos de liberação nessa cidade não fragilizou o poder constituído a ponto deste se abrir para a experimentação de novas formas de poder e dominação.

Negri destaca, no entanto, que a resistência à autodissolução revela certa vitalidade mínima da liberdade em Florença. Além do que, a cidade teria resistido a imitar os modelos de segurança e fortaleza advindos da tradição medieval. Florença seria assim uma experiência antiutópica, expressão da não realização da liberdade constituinte na modernidade, exemplo de soberania democrática sempre em vias de ser completada, quando não em decadência visível. Sobre esse aspecto ela não teria efetivado sequer a soberania em sentido pleno. Projetando tais análises sobre as experiências da democracia moderna, cabe perguntar: as instituições que acolhem a liberdade e o conflito estariam fadadas a repetir os percalços e as mazelas políticas de Florença?; ou, os movimentos da potência constituinte estariam condenados a repetir a dominação desmedida de todas as soberanias, tal como constata Agamben?

Vimos que, após as observações críticas de Agamben acerca da soberania, a potência constituinte negriana não pode ser pensada isolada da potência destituinte. Defensor da emancipação da multidão, Negri sustenta que o maior legado de Maquiavel para a modernidade e os que a sucedem é demonstrar de que a experiência radical da liberdade não 
se encerra em um modelo estático de conflito, de instituições políticas, de Estado, de soberania. A experiência constituinte da liberdade será sempre abertura para a possibilidade de novas sobredeterminações do tempo e da história, novas experiências democráticas que, por sua potência constituinte e destituinte, fragilizem a ordem constituída para dar origem a novas formas do comum. Sobre esse aspecto concordamos com Negri em relação à avaliação talvez fatalista de Agamben.

Aos críticos da suposta falta de precisão -anacronismos, simplificações- nas leituras de Negri acerca de Maquiavel e da modernidade, Lucchese (2014) responde que só se pode entender tal interpretação se a localizamos no interior de um trabalho mais amplo de formulação das filosofias políticas moderna e contemporânea. Por mais que a abordagem pareça estranha aos intérpretes atados aos preciosismos da literatura acadêmica tradicional, não haveria como deixar de admitir que Maquiavel está no coração do trabalho formulador da liberdade e do poder constituinte. Junto com Marx e Espinosa,

Maquiavel pertence a uma alternativa metafísica e política do pensamento moderno fundamentada em uma versão revolucionária do poder constituinte. Enquanto esses três autores trabalham para estabelecer uma versão absoluta e indomável do poder constituinte, os autores pertencentes ao trabalho alternativo liberal e constitucional trabalham por sua dissolução e obliteração dentro do poder constituído. No choque entre essas duas tradições, Negri reconhece a contradição e o conflito fundamental da história jurídica moderna. Reavaliar a alternativa revolucionária da modernidade é o primeiro passo no reconhecimento de seus limites em contextos históricos. É um passo necessário para explicar como a principal alternativa tem historicamente conseguido reabsorver o poder constituinte no poder constituído (pode-se falar de trabalho vivo e trabalho morto, tal como 
Negri faz, emprestando as categorias de Marx). Isso prepara o terreno para o surgimento teórico de um novo assunto absoluto do poder constituinte (2014, p.04).

Por fim, podemos ainda indagar se a leitura atenta do projeto Homo Sacer não teria feito Negri avançar por outros caminhos além da tentativa de formular uma concepção de soberania democrática. Por exemplo, seu projeto de avaliação da soberania contemporânea e de formulação de uma perspectiva política liberadora do poder constituído contemplaria alguma dimensão ética, tal com já a encontramos em Agamben?

Uma resposta talvez a possamos encontrar em Assembly (2017). Nessa obra, Negri se pergunta: por que os movimentos emancipatórios contemporâneos não foram capazes de efetuar a mudança e criar a nova, mais democrática e justa sociedade? $\mathrm{O}$ pensador vê como tarefa urgente e necessária a crítica sobre os modos coletivos de condutas e os tipos de lideranças que os movimentos emancipatórios contemporâneos congregam. Nessa obra está em questão não apenas o status de certos movimentos dotados da potência constituinte, mas o autor se pergunta pelo tipo de subjetividade daqueles que se engajam na liberação. O problema da potência constituinte não se reduziria, então, a investigar o modo como se tomará o poder, ou como este será reformulado a fim de que se instaure a liberdade. É preciso repensar os princípios que amparam os atos e o engajamento dos ocupantes de um poder diferente e fundamentalmente novo, de uma sociedade democrática e, crucialmente, produtora de novas subjetividades (2017, p.xviiiii).

Confirmando nossa impressão manifesta acima, outros 
fios de conexão se podem notar entre os trabalhos filosóficopolíticos de Negri e Agamben. Deixemos para outro momento a investigação sobre as questões éticas que, em ambos projetos, envolvem a produção de novas formas de vida e de subjetividades atuantes em face do poder constituído e da dominação soberana.

Abstract: This article investigates Antonio Negri's (2002) analysis of Machiavelli's works on democracy, taking into consideration the concepts of conflict, political ontology, and constituent potential. According to Negri, the democratic sovereignty overdetermines the government's actions when in face of the resistances presented both by opponents and fortune. The politics principle is the activity that results from the movements for the expansion of freedom confronted to the ones of constraint and institution of the anti-freedom paralysis. For Negri, this conception of the political conflict is at the core of the Machiavelli's definition of political ontology. In Rome and Florence, conflicts and riots as well as the lost of legitimacy by both tyranny and the nobility's oppression of the people could show historically this movement of creation and destruction of liberty. Negri presents his views on the destituent potential based on Agamben's Homo Sacer project. Certain passages of History of Florence can show us the paralysis that comes from the riots and the limits of both the constituent and the destituent potential. Our hypothesis is that the perception of those limits can connect Negri's philosphical and political approach to an evaluation of the ethical principles for action, aiming at the creation of new ways of life and liberating subjectivities.

Keywords: Negri. Machiavelli. Democratic sovereignity. Political ontology. Constituent power.

\title{
REFERÊNCIAS
}

\author{
AGAMBEN, G. L'uso dei corpi. Vicenza: Neri Pozza Edi- \\ tore, 2014.
}

Stasis - la guerra civile come paradigma politico. Torino: Bollati Boringhieri, 2015.

. Homo Sacer - poder soberano e vida nua. Belo Horizonte: Ed. UFMG, 2002. 
ARENDT, H. Sobre a revolução. São Paulo: Companhia das Letras, 2011.

BIGNOTTO, N. Maquiavel republicano. São Paulo: Loyola, 1991.

DIRAN, I. Negri. In.: KOTSKO, A. \& SALZANI, C. (eds.). Agamben's Philosophhical lineage. Edinburgh: Edinburgh University Press, 2017.

LORAUX, N. La guerre dans la famille. In.: Clio, Histoire, femmes et sociétés, Vol.5,1997a, Disponível em: http://journals.openedition.org/clio/407 ;

DOI : 10.4000/clio.407 Acesso em: 14/09/2018.

. La cité divisé. L'oubli dans la mémoire d'Athènes. Paris: Payot, 1997 b.

LUCCHESE, Filippo del. "Machiavelli and constituent power: The revolutionary foundation of modern political thought". In.: European Journal of Political Theory. Published online at 25 July 2014. DOI: 10.1177/1474885114544911. Disponível em: http://ept.sagepub.com/content/early/2014/07/24/147488511454491c Acesso em: 20/10/2017.

MAQUIAVEL, N. L'esilio di San Casciano - 10 dicembe 1513. In.: Opere Scelete. Roma: Editori Riuniti, 1981.

. Tutte le Opere. Firenze: Sansoni, 1992.

. História de Florença. São Paulo: Musa Editorial, 1998.

MORFINO, Vittorio. The Multitudo According to Negri: On the Disarticulation of Ontology and History. Rethinking 
Marxism, Vol. 26, No. 2, 227-238, agosto, 2014.

http://dx.doi.org/10.1080/08935696.2014.888851

NEGRI, A. O poder constituinte. Rio de Janeiro: L\&PM, 2001.

- "Sovereignty between government, exception and governance". In.: SKINNER, Q. \& KALMO, H. Sovereignty in fragments - The past, presente and future of a contested concept. Cambridge: University Press, 2010. pp. 205-221.

\& HARDT, M. Revolution retrieved. Londres: Red Notes, 1988.

\& HARDT, M. The Savage Anomaly. Oxford: University of Minnesota Press, 1991.

\& HARDT, M. Time for revolution. New York: Continuum, 2003.

\& HARDT, M. Império. Rio de Janeiro: Record, 2001.

\& HARDT, M. Multidão: Guerra e democracia na era do Império: Guerra e democracia na era do Império. Rio de Janeiro: Record, 2005.

\& HARDT, M. Bem-estar comum. Rio de Janeiro: Record, 2016.

\& HARDT, M. Assembly. Oxford: Oxford University Press, 2017.

Agamben: quando a inoperosidade é soberana. In.:

Adital-IHU-Unisinos. 24/11/2014. Disponível em: 
http://www.ihu.unisinos.br/noticias/537757-agambenquando-a-inoperosidade-e-soberana-artigo-de-toni-negri Acesso em: 22/09/2018.

SCHMITT, C. O nomos da terra. No Direito das Gentes do Jus Publicum Eruropaeum. Rio de Janeiro: Contraponto, 2014.

SKINNER. As Fundações do pensamento político moderno. São Paulo: Companhia das Letras, 2003. 